\title{
LOW NEUTRAL GENETIC DIVERSITY IN AN ISOLATED GREATER SAGE GROUSE (CENTROCERCUS UROPHASIANUS) POPULATION IN NORTHWEST WYOMING
}

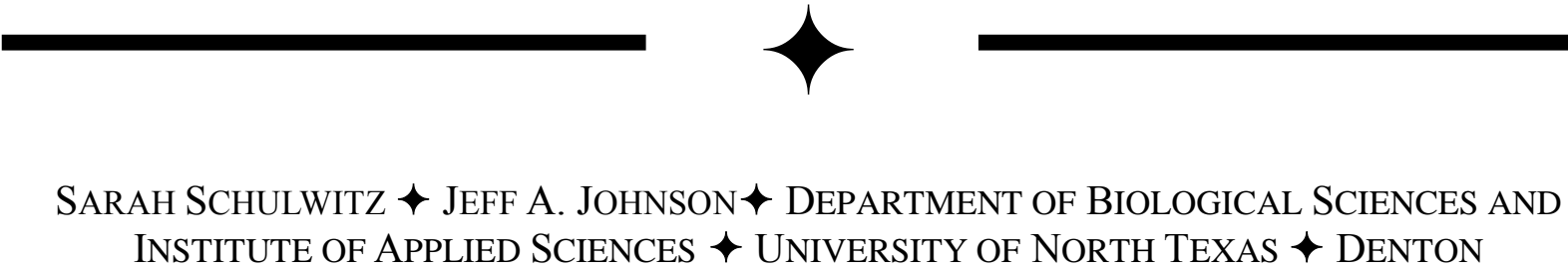

BRYAN BEDROSIAN $\uparrow$ CRAIGHEAD BERINGIA SOUTH $\uparrow$ KELLY, WY

\begin{abstract}
$\downarrow$ ABSTRACT
Habitat loss is well recognized as an immediate threat to biodiversity. Depending on the dispersal capabilities of the species, increased habitat fragmentation often results in reduced functional connectivity and gene flow followed by population decline and a higher likelihood of eventual extinction. Knowledge of the degree of connectivity between populations is therefore crucial for better management of small populations in a changing landscape. A small population of greater sage-grouse (Centrocercus urophasianus) exists in northwest Wyoming within the Jackson Hole valley, including Grand Teton National Park and the National Elk Refuge. To what degree the Jackson population is isolated is not known as natural dispersal barriers in the form of mountains and anthropogenic habitat fragmentation may limit the population's connectivity to adjacent populations. Using 16 microsatellite loci and 300 greater sage-grouse samples collected throughout Wyoming and southeast Montana, significant population differentiation was found to exist among populations. Results indicated that the Jackson population was isolated relative to the other sampled populations, including Pinedale, its closest neighboring large population to the south. The one exception was a small population immediately to the east of Jackson, in which asymmetric dispersal from Jackson into Gros Ventre was detected. Both Jackson and Gros Ventre populations exhibited significantly reduced levels of neutral genetic diversity relative to other sampled populations. More work is warranted to determine the timing at which Jackson and Gros Ventre
\end{abstract}

populations had become isolated and whether it was primarily due to recent habitat fragmentation or more historic processes. Due to its small population size, continual monitoring of the population is recommended with the goal of at least maintaining current population size and, if possible, increasing suitable habitat and population size to levels recorded in the past.

\section{$\downarrow \quad$ INTRODUCTION}

Habitat degradation and fragmentation due to human mediated activities are considered primary factors contributing to global biodiversity decline (Sala et al. 2000; Fahrig 2003; Baillie 2004). As habitat is lost, populations become increasingly distant from each other leading to reduced gene flow and loss of genetic diversity through drift (Reed 2004; Frankham 2005; Ezard and Travis 2006; see also Johnson et al. 2003, 2004; Dixo et al. 2009; Delaney et al. 2010). This pattern is becoming increasingly pervasive throughout human inhabited environments with many species possessing isolated populations of various size and associated fitness related consequences (Westemeier et al. 1998; Madsen et al. 1999; Blomqvist et al. 2010; Fei et al. 2011). Isolated or peripheral populations may be more susceptible to environmental and demographic stochasticity due to factors limiting their distribution and other conditions such as minimal gene flow and small population size (e.g., Peterman et al. 2013). Therefore, these populations are of important conservation concern (Channell and Lomolino 2000) especially given that many isolated or peripheral populations often harbor unique genetic diversity 
(Nielsen et al. 2001). Much work has focused on identifying recently isolated populations in an effort to help inform management and thereby mitigate potential fitness consequences that may contribute to local extirpation and ultimately species extinction (Kyle and Strobeck 2002; Segelbacher et al. 2003; Ratkiewicz et al. 2012; also see Henle et al. 2004; Prevedello and Vieira 2010).

Sagebrush-steppe habitat in North America is one example where dramatic land-use changes over the past century have resulted in the isolation and decline of many sagebrush dependent species (Knick et al. 2002, 2003; Rowland et al. 2011). The sagebrush biome (Artemesia spp.) was once a dominant habitat type across much of northwest United States, but has been recently altered by human-mediated practices including agriculture, livestock grazing, infrastructure development, energy exploration and extraction for oil and gas, invasive species (e.g. cheatgrass, Bromus tectorum), and changes in fire regime (Knick and Connelly 2011). Many of these factors have a cumulative effect, resulting in sagebrush habitat fragmentation, degradation, and loss. Accordingly, animals considered sagebrush obligates, including Brewer's sparrow (Spizella breweri), pygmy rabbit (Brachylagus idahoensis), and pronghorn (Antilocapra americana), have responded negatively to habitat alteration and fragmentation and are of increasing conservation concern due to decreased abundance (Baker 1976; Knick and Rotenberry 2002; Rowland et al. 2006). For example, the pygmy rabbit has experienced a significant decline in population size and was listed as an Endangered Species in 2003 (USFWS 2003). Likewise, energy development activities have been shown to displace mule deer (Odocoileus hemionus), and increasing concern exists that the removal and disruption of migration corridors for mule deer and pronghorn may have negative impacts on their long-term population sustainability (Sawyer et al. 2005, 2006).

The greater sage-grouse (Centrocercus urophasianus, hereafter referred to as sage-grouse) is a sagebrush obligate that has also experienced range-wide population decline and contraction and now occupies approximately $56 \%$ of its pre-European settlement distribution (Schroeder et al. 2004). Populations of this species have become increasingly fragmented and isolated and, consequently, have received widespread political and conservation attention (Oyler-McCance et al. 2005; Walker et al. 2007; Aldridge et al. 2008). In 2010, the United States Fish and Wildlife Service determined that sage-grouse deserved protection under the Endangered Species Act, yet protection was precluded due to higher priority cases. It is currently a candidate for protection under the Endangered Species Act with a final decision due by the end of fiscal year 2015 .

Recent work investigating connectivity among sage-grouse populations throughout their entire geographic distribution identified a total of ten distinct population-level clusters based on genetic methods (Oyler-McCance et al. 2005). The majority of these clusters, however, were explained largely by isolation by distance (IBD) suggesting connectivity among the primary core regions (i.e., southeast Oregon, northeast Nevada, southern Idaho and much of Wyoming and eastern Montana; Oyler-McCance et al. 2005; see also Bush et al. 2011). Several small, isolated populations were also identified, located on the periphery of the species' current range in Colorado, Utah, Washington, and on the California/Nevada border, some of which had reduced genetic diversity compared to populations sampled in the core of the species' range (OylerMcCance et al. 2005). Many of these isolated populations have resulted from recent habitat fragmentation (i.e. see Schroeder et al. 2004; OylerMcCance et al. 2005). As sagebrush habitat is lost, isolated populations will continue to decline in size and lose genetic diversity by genetic drift, further reducing population viability and increasing risk of extirpation (Frankham 2005), a common theme among lekking grouse in general (i.e., extinction vortex; Soule and Mills 1998).

The primary objective of this study was to assess the degree of isolation and level of genetic diversity of a relatively small sage-grouse population located in the Jackson Hole valley of northwest Wyoming (herein referred to the Jackson population). The current Jackson sage-grouse population is estimated to be between 300 and 500 individuals, existing primarily on protected federal land (Grand Teton National Park and the National Elk Refuge) with an area of approximately 9,500 hectares of sagebrush habitat (B. Bedrosian, unpubl. data; see also Garton et al. 2011). To what degree this population is isolated from surrounding sage-grouse populations is not known, but potential dispersal barriers do exist surrounding this population, including forested mountains to the west, east and southeast, the city of Jackson to the south and Yellowstone plateau with more forested high elevation habitat to the north (Figure 1). Furthermore, recent anthropogenic habitat changes and increasing human presence (i.e., development and park visitation rates) have occurred in areas immediately adjacent to Jackson, potentially increasing the distance to larger sage-grouse populations to the south (i.e., Sublette County). This is Figure 1. Approximate locations of sage-grouse populations sampled throughout Wyoming with sample size in 


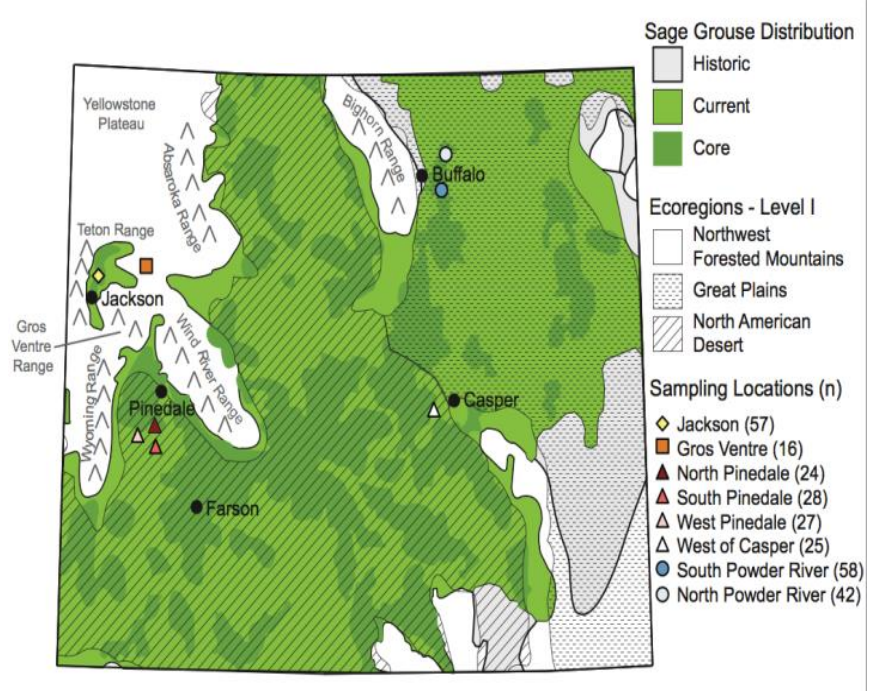

parentheses. A population in southeast Montana was also sampled ( $\mathrm{n}=23$; not shown on map). Historic, current, and core sage-grouse distributions indicated in grey, light and dark green, respectively (adapted from Schroeder et al. 2004 and from the Sage-Grouse Core Management Areas Version 3 Map, see http://wyofile.com/wp-content/uploads/2011/ 08/sg coreareas.jpg). Northwest Forested Mountains, North American Desert, and Great Plains level I ecoregions indicated with blank, striped, and dashed patterning, respectively (also see Olson et al. 2001 and ftp://ftp.epa.gov/wed/ecoregions/cec na/NA LEVEL I.pdf). Major mountain ranges and geographic features near Jackson indicated in grey.

of concern because the current distance to the nearest sage-grouse population is much greater than the species' average dispersal distance (Knick and Connelly 2011).

Telemetry studies have not recorded any Jackson sage-grouse dispersing to other locations (B. Bedrosian,unpubl. data, Holloran and Anderson 2004). Thus, evidence suggests that current barriers to dispersal, whether natural or anthropogenic, may be sufficient to prevent gene flow between the Jackson sage-grouse population and other populations in Wyoming. Depending on current levels of genetic diversity and connectivity, the Jackson sage-grouse population may warrant immediate management to prevent its extirpation.

\section{$\uparrow \quad$ METHODS}

\section{Tissue collection and DNA extraction}

Blood samples were collected from yearling and adult sage-grouse over a five year period (20052010) between March and May from eight geographic locations in Wyoming and one in southeastern Montana (Table 1, Figure 1). Samples were collected from
Jackson Hole $(n=57)$ and Gros Ventre $(n=16$; Teton County), from three locations near Pinedale (Sublette County) designated north $(\mathrm{n}=24)$, south $(\mathrm{n}=28)$, and west $(n=27)$ Pinedale, west of Casper $(n=25$; Natrona County), and in Powder River Basin east of Buffalo (Johnson County) designated north $(\mathrm{n}=42)$ and south $(\mathrm{n}=58)$ Powder River. Additional samples were collected in southeast Montana $(n=23$; Carter County) and designated SE Montana. DNA was extracted from a total of 300 samples using the DNeasy Blood and Tissue Kit following manufacturer's protocols (QIAGEN Inc.).

\section{Genotyping}

Seventeen microsatellite loci were chosen based on previous sage-grouse population genetic studies (Oyler-McCance et al. 2005; Bush et al. 2011). Microsatellite loci were originally developed for greater sage-grouse (SGCA11.2, Oyler-McCance et al. 2011; reSGCA5, reSGCA6, and reSGCA9, Oyler-McCance pers. comm.), Gunnison sage-grouse (Centrocercus minimus; SGMS06.4, SGMS06.6, SGMS06.8, MSP7, MSP11, MSP18; Oyler-McCance and St. John 2010), capercaillie (Tetrao urogallus; TUD3, TUT3, TUT4, Segelbacher et al. 2000) and black grouse (Tetrao tetrix; TTD6, Caizergues et al. 2001; BG6, BG14, Piertney and Höglund 2001; TTT3, Caizergues et al. 2003). SGMS06.6 was a trinucleotide repeat and SGMS06.4, SGMS06.8, BG6, BG14, TUT3, TUT4, and TTT3 were tetranucleotide repeats; all remaining loci were dinucleotide repeats.

Polymerase chain reactions (PCR) were optimized and modified slightly from previously published methods that described protocols for each locus. A fluorescently labeled forward primer and an unlabeled reverse primer were used in PCRs. Each reaction was performed in $10 \mu \mathrm{L}$ final volume with final concentrations of $100 \mu \mathrm{M}$ each dNTP, 1x PCR buffer, and $0.1 \mu \mathrm{L}$ (0.5 units) GoTaq Flexi DNA polymerase (Promega). A final concentration of $1.0 \mathrm{mM}$ of each primer was used for SGMS06.4, SGMS06.8, MSP7, MSP18, and SGCA11.2 and $0.25 \mathrm{mM}$ for the remaining loci. $\mathrm{MgCl}_{2}$ concentrations ranged from $1.0 \mathrm{mM}$ (SGMS06.8) to $1.5 \mathrm{mM}$ (SGMS06.4, MSP7, MSP18, and SGCA11.2) and $2.25 \mathrm{mM}$ (remaining loci) per PCR reaction. Thermal profiles for all loci except TTD6 consisted of $2 \mathrm{~min}$ at $94^{\circ} \mathrm{C}, 35$ cycles of $30 \mathrm{~s}$ at $94^{\circ} \mathrm{C}, 30$ $\mathrm{S}$ at the specified annealing temperature described elsewhere (Segelbacher et al. 2000; Piertney and Höglund 2005; Oyler-McCance and St. John 2010; Oyler-McCance et al. 2011) with the exception of SGMS06.4, SGMS06.8, and TTT3 $\left(59.9^{\circ} \mathrm{C}, 55.4^{\circ} \mathrm{C}\right.$ and $58^{\circ} \mathrm{C}$, respectively), and $30 \mathrm{~s}$ at $72^{\circ} \mathrm{C}$, and a final $5 \mathrm{~min}$ extension at $72^{\circ} \mathrm{C}$. The thermal profile for TTD6 followed that described in Caizergues et al. (2001). Each 
amplified product was genotyped using an ABI 3130xl Genetic Analyzer and analyzed with the program GeneMarker v.1.6 (Soft Genetics, LLC.).

\section{Statistical Analyses}

Genetic diversity. -- Microsatellite genotypes were tested for linkage disequilibrium and departure from Hardy-Weinberg Equilibrium (HWE) within each population and locus using the program GDA v. 1.1 (Lewis and Zaykin 2001). Sequential Bonferroni corrections were used to correct for multiple simultaneous comparisons (Rice 1989). Mean number of alleles per locus $(A)$, observed $\left(H_{o}\right)$ and expected $\left(H_{e}\right)$ heterozygosity, and inbreeding coefficient $(f)$ were calculated using GDA, and allelic richness $(A R)$ was estimated using FSTAT v. 2.9.3.2 (Goudet 1995). $A R$ provides an estimate of allelic diversity that controls for differences in samples size (Leberg 2002).

To assess genetic variability among sampling locations, we compared $A R, H_{O}$, or $H_{E}$ using a one-way analysis of variance (ANOVA) on ranked data, blocked by locus in order to control for interlocus variation ( $\alpha=0.05$; SAS 9.3, SAS Institute, Cary, NC, USA). Significant findings were further analyzed using an $a$ posteriori Student-Newman-Keuls multiple comparison test on ranked data to determine groups with means that did not significantly differ from each other. Values for $f$ were considered significant if their 95\% confidence interval as calculated with GDA did not overlap with zero.
Population connectivity.-- Principal Coordinate Analysis (PCoA) implemented in the Excel-based genetic analysis program GenAlEx v. 6.5 (Peakall and Smouse 2006) was used to visualize whether any patterns were observed that corresponded with sample location. The genetic distance (GD) matrix used in the PCoA was calculated using the Distance option (Peakall and Smouse 2006). One PCoA was conducted that included all populations, and two additional PCoAs were conducted corresponding to the identified clusters from STRUCTURE (see below; see also Figure 2).

To assess genetic differentiation between sampled sage-grouse populations, pairwise $F_{\text {ST }}$ values were calculated following Weir and Cockerham (1984) as implemented in Arlequin v. 3.11 (Excoffier et al. 2005). Differences in population structure between sampling locations were tested using 1000 permutations among populations with Fisher's exact test. In addition, the Bayesian method of Pritchard et al. (2000) as implemented in STRUCTURE v. 2.3.4 was used to identify the most likely number of genetic clusters $(K)$ among sampled individuals. This method identifies genetically distinct clusters based on maximizing Hardy-Weinberg equilibrium and linkage equilibrium among samples. Each simulation from $K=1$ to 10 was performed 20 times using a burn-in of 100,000 followed by 500,000 iterations while allowing for admixture, an individual $\alpha$ for each cluster, and a model of correlated allele frequencies that did not include prior information on population origin (see Falush et al. 2003). STRUCTURE was run to determine the most likely number of clusters for all populations.

Table 1. Measures of mean nuclear microsatellite genetic diversity for 16 loci for sage-grouse populations in Wyoming and southeast Montana. $n$, sample size; $A$, mean number of alleles; $A R$, allelic richness; $H_{e}$, expected heterozygosity; $H_{o}$, observed heterozygosity; $f$, inbreeding coefficient; $N_{\mathrm{e}}$, effective population size. Letters as subscripts for $A R, H_{\mathrm{o}}$ and $H_{\mathrm{e}}$ indicate groups that are not significantly different $($ alpha $=0.05)$.

\begin{tabular}{cccccccc}
\hline Locality & $n$ & $A$ & $A R$ & $H_{o}$ & $H_{e}$ & $f$ & $N_{\mathrm{e}}(95 \% \mathrm{CI})$ \\
\hline Jackson & 57 & 7.0 & $6.1_{\mathrm{c}}$ & $0.685_{\mathrm{b}}$ & $0.732_{\mathrm{bc}}$ & $0.065^{*}$ & $91(68-131)$ \\
Gros Ventre & 16 & 5.5 & $5.5_{\mathrm{c}}$ & $0.66 \mathrm{~b}_{\mathrm{b}}$ & $0.695 \mathrm{c}$ & 0.052 & $21(15-32)$ \\
North Pinedale & 24 & 9.7 & $8.8_{\mathrm{ab}}$ & $0.794_{\mathrm{a}}$ & $0.806_{\mathrm{a}}$ & 0.015 & infinite $(232-$ infinite $)$ \\
South Pinedale & 28 & 11.2 & $9.4_{\mathrm{a}}$ & $0.779_{\mathrm{ab}}$ & $0.807_{\mathrm{a}}$ & 0.036 & $960(205-$ infinite $)$ \\
West Pinedale & 27 & 10.5 & $9.1_{\mathrm{a}}$ & $0.794_{\mathrm{ab}}$ & $0.805_{\mathrm{a}}$ & 0.013 & infinite (2043-infinite) \\
West of Casper & 25 & 9.8 & $8.5_{\mathrm{ab}}$ & $0.780_{\mathrm{a}}$ & $0.790_{\mathrm{a}}$ & 0.013 & infinite (-439-infinite) \\
South Powder River & 24 & 9.6 & $7.7_{\mathrm{b}}$ & $0.754_{\mathrm{ab}}$ & $0.765_{\mathrm{ab}}$ & 0.014 & $215(193-$ infinite $)$ \\
North Powder River & 58 & 9.6 & $7.6_{\mathrm{b}}$ & $0.748_{\mathrm{ab}}$ & $0.774_{\mathrm{ab}}$ & $0.034^{*}$ & $87(71-111)$ \\
SE Montana & 23 & 8.9 & $8.1_{\mathrm{ab}}$ & $0.755_{\mathrm{ab}}$ & $0.779_{\mathrm{a}}$ & 0.03 & $188(97-1543)$ \\
\hline
\end{tabular}

* inbreeding coefficient is significantly different from zero. 
A)
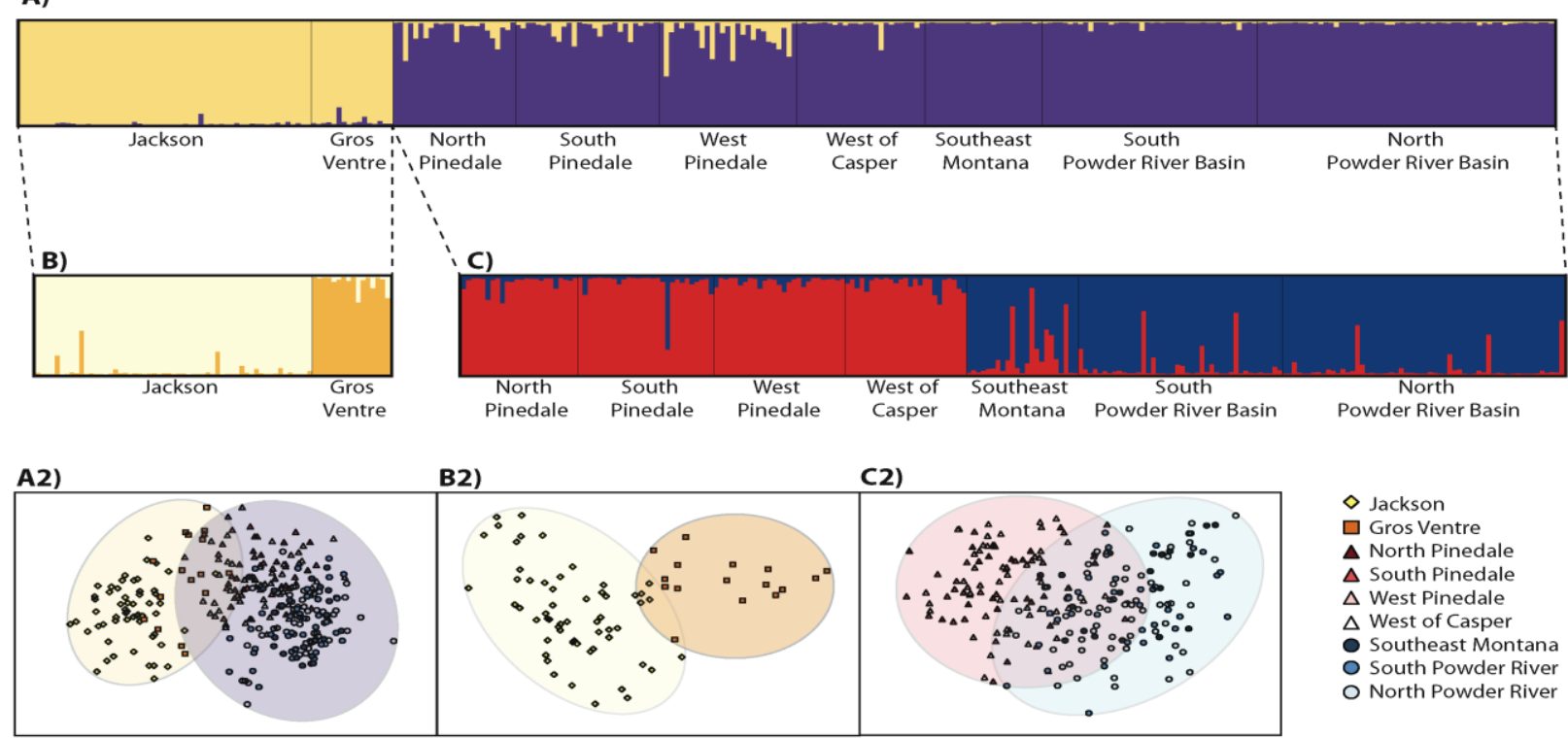

$\diamond$ Jackson

$\square$ Gros Ventre

$\Delta$ North Pinedale

$\Delta$ South Pinedale

$\triangle$ West Pinedale

$\triangle$ West of Casper

Southeast Montana

O South Powder River

O North Powder River

Figure 2. Bayesian clustering of sage-grouse using STRUCTURE based on 16 microsatellite loci in (A) eight sampling locations throughout Wyoming and one in Montana, (B) Jackson and Gros Ventre only, and (C) Pinedale, Casper, Powder River, and Montana sampling locations only. Each color represents a distinct cluster. Principal coordinate analysis (PCoA; A2, B2 and C2) corresponds to each of the sampling strategies used with STRUCtURE (A, B, and C, respectively).

Additional STRUCTURE analyses were performed to determine if further population structure existed within each of the initially identified clusters. STRUCTURE was also run with the exclusion of the Powder River and Montana populations to determine the relationship between Jackson, Gros Ventre, and Pinedale populations. The web-based program StRUCTURE HaRvester v. A.1 (Earl and vonHoldt 2012) and the Evanno $\Delta K$ method (Evanno et al. 2005) were used to determine the mostly likely number of genetically distinct clusters $(K)$. The program CLUMPP v. 1.1.2 (Jakobsson and Rosenberg 2007) was used to compile replicate runs results from STRUCTURE, and the program DISTRUCT v. 1.1 was used to visualize results (Rosenberg 2007).

Several modules within BAPS v. 5.3 (Corander et al. 2008b) were used as an additional method to identify genetic structure among sample locations. We ran 'population mixture analysis' with clustering of individuals with and without spatial coordinate information. Spatial information allowed the program to assign a non-random distribution based on biologically relevant population information thereby allowing for increased power to detect population structure (Corander et al. 2008b). We also ran population admixture analysis based on mixed clustering (Corander and Marttinen 2006; Corander et al. 2008a). Each module was run for $K=1$ to 10 .
Correlations between genetic similarity (M) and geographic distances among populations (i.e. isolation by distance, IBD) were evaluated using the program Isolation By Distance Web Service v. 3.23 (IBDWS; Jensen et al. 2005). The program performs a Mantel test with pairwise matrices of geographic distance and Slaktin's (1993) measure of similarity, $\mathrm{M}=[(1 / \mathrm{FST})-1] / 4$. Significance of IBD was tested with a Mantel procedure (10,000 permutations). Geographic distances between each population were measured using Google Earth.

To estimate the rates and direction of recent migration among populations, the Bayesian method for multilocus genotype data, BAYESASS $\vee 3.0 .3$, was implemented (Wilson and Rannala 2003). Because simulation studies show that the method's accuracy decreases with increased numbers of populations analyzed (Faubet et al. 2007), final analyses were conducted after combining sampling locations into four populations according to results obtained from STRUCTURE (see below). Specifically, data for the Pinedale and Casper locations were clustered into a single population, data for the Powder River/Montana locations were clustered into a single population, and Jackson and Gros Ventre were included as independent populations. Mixing parameters were adjusted according to the user's manual to obtain acceptance rates between $20-60 \%$. Specifically, default delta values for migration rates were kept at 0.10 , while delta values for allele frequencies and inbreeding were 
0.30. The program was performed with a burn-in of $7.0 \times 10^{6}$ generations, $2.7 \times 10^{7}$ iterations, and sampling frequency of 1000 . To ensure consistent estimates, ten runs were conducted with different seed numbers. A rough $95 \%$ credible set around the posterior mean was calculated using the provided mean and standard deviation according to the user's manual.

Effective population size. -- Estimates of effective population size $\left(N_{\mathrm{e}}\right)$ were calculated for each population using the linkage disequilibrium method as implemented in LDNe v. 1.31 (Waples and Do 2008). Alleles with frequencies $<0.02$ were excluded (Waples 2006), and 95\% confidence intervals for $N_{\mathrm{e}}$ were obtained using the jackknife option (Waples and Do 2008).

\section{$\downarrow \quad$ RESULTS}

\section{Genetic diversity measures}

All loci were polymorphic with a range of 2 to 24 alleles per locus in each population. After adjusting for multiple comparisons, the majority of loci possessed no significant deviations from HWE or showed signs of linkage. Locus TUD3, however, showed significant heterozygote deficiency in four populations (Jackson, North Pinedale, West Pinedale, and Casper), and was excluded from all subsequent analyses.

Significant differences in $A R, H_{o}$, and $H_{e}$ were observed between sampled sage-grouse populations (Table 1). Overall, the Pinedale and Casper populations exhibited the highest measures of neutral genetic diversity, SE Montana and each of the Powder River populations possessed intermediate levels, and Jackson and Gros Ventre had the lowest diversity values. Significant inbreeding coefficients $(f)$ were observed for the Jackson and North Powder River Basin populations, while all other populations were not significantly different from zero.

\section{Analyses of population structure}

Multiple methods indicated that Jackson was isolated from all other sampled sage-grouse populations. The PCoA showed limited differentiation among the majority of sampled sage-grouse populations with the exception of the Jackson population, which formed a separate distinct cluster, and to a lesser degree the Gros Ventre population, in which approximately half the individuals clustered with Jackson and the remaining clustered in an overlapping zone between Jackson and the other sampled populations (Figure 2). When all populations were analyzed together, the first three coordinates accounted for $30.9,15.8$, and $14.9 \%$ of the variation, respectively.

Pairwise $F_{\mathrm{ST}}$ values showed evidence of population differentiation among sampled locations with the highest values observed between comparisons with Jackson (range: 0.070-0.111) and also Gros Ventre (range: 0.073-0.109; Table 2). Pairwise $F_{\text {ST }}$ values were significant ( $\alpha=0.001$ ) for all populations except those between areas within Pinedale and between North Pinedale and the Casper population (Table 2).

Results from STRUCTURE also indicate that Jackson and Gros Ventre were significantly differentiated from all other sampled locations, with $K=2$ as the most likely number of genetic clusters when all nine sampling locations were analyized as a

Table 2. Population pairwise $F_{\mathrm{ST}}$ comparisons based on 16 asterisk microsatellite loci. ${ }^{*}, P<0.001$.

\begin{tabular}{|c|c|c|c|c|c|c|c|c|}
\hline & Jackson & $\begin{array}{l}\text { Gros } \\
\text { Ventre }\end{array}$ & $\begin{array}{l}\text { North } \\
\text { Pinedale } \\
\end{array}$ & $\begin{array}{l}\text { South } \\
\text { Pinedale } \\
\end{array}$ & $\begin{array}{l}\text { West } \\
\text { Pinedale }\end{array}$ & $\begin{array}{l}\text { West of } \\
\text { Casper }\end{array}$ & $\begin{array}{l}\text { S Powder } \\
\text { River }\end{array}$ & $\begin{array}{l}\text { N Powder } \\
\text { River }\end{array}$ \\
\hline Gros Ventre & $0.088^{*}$ & - & & & & & & \\
\hline North Pinedale & $0.073 *$ & $0.084^{*}$ & - & & & & & \\
\hline South Pinedale & $0.084 *$ & $0.079^{*}$ & 0.004 & - & & & & \\
\hline West Pinedale & $0.070^{*}$ & $0.073^{*}$ & 0.007 & 0.006 & - & & & \\
\hline West of Casper & $0.093 *$ & $0.109^{*}$ & 0.009 & $0.021 *$ & $0.021 *$ & - & & \\
\hline S Powder River & $0.101 *$ & $0.104 *$ & $0.025^{*}$ & $0.034 *$ & $0.035^{*}$ & $0.035^{*}$ & - & \\
\hline N Powder River & $0.103^{*}$ & $0.103^{*}$ & $0.027 *$ & $0.039 *$ & $0.036^{*}$ & $0.030^{*}$ & $0.008^{*}$ & - \\
\hline SE Montana & $0.111^{*}$ & $0.107 *$ & $0.033^{*}$ & $0.037 *$ & $0.040^{*}$ & $0.046^{*}$ & $0.019^{*}$ & $0.023 *$ \\
\hline
\end{tabular}

Significant values (alpha $<0.001)$ are indicated by an asterisk. 
single dataset (Figure 2). Specifically, Jackson and Gros Ventre formed a single cluster, and individuals from the remaining sampling locations formed the second cluster (see Figure 1). Within each cluster, further substructure was also observed, specifically between Jackson and Gros Ventre $(K=2)$ and between Powder River Basin/Montana and Pindale/Casper $(K=2$; Figure 2) when analyzed separatelybetween Jackson and Gros Ventre $(K=2)$ and between Powder River Basin/Montana and Pinedale/Casper $(K=2$; Figure 2) when analyzed separately.

Analysis with BAPS confirmed previous results that the Jackson population was isolated from other sampled populations. This result was consistent regardless of inclusion of spatial information or admixture in the model. When spatial information was excluded from the model, four main clusters were identified that corresponded with Jackson, Gros Ventre, Pinedale/Casper, and Powder River/SE Montana. When spatial information was included, two clusters were identified with Jackson clustering separately from all other populations, including Gros Ventre. When admixture was included, three main clusters were identified, with Jackson and Gros Ventre forming a single cluster, and Pinedale/Casper and Powder River/SE Montana forming the remaining two clusters.

\section{Isolation-by-distance analyses}

Using microsatellite data from all sampled locations, there was a significant relationship between geographic distance $(\mathrm{km})$ and $\log$ genetic similarity $\left(r^{2}\right.$ $=0.175, P=0.025$; Figure 3 ). However, all pairwise comparisons with Jackson and Gros Ventre possessed relatively low levels of genetic similarity regardless of geographic distance (Figure 3; see also Table 2). This was further shown when Jackson and Gros Ventre were excluded from the analysis, by showing a stronger IBD relationship $\left(r^{2}=0.606, P=0.001\right.$; Figure 3).

\section{Contemporary migration}

Based on estimates from BAYESASS, a high proportion of individuals were derived from their own populations $(>0.96)$ for all clusters except Gros Ventre (0.82; Table 3$)$. Accordingly, recent immigration rates among the majority the four clusters were low $(m<$ 0.03 ) with the exception that a moderate portion of the individuals sampled in Gros Ventre were migrants derived from Jackson $(m=0.10)$.

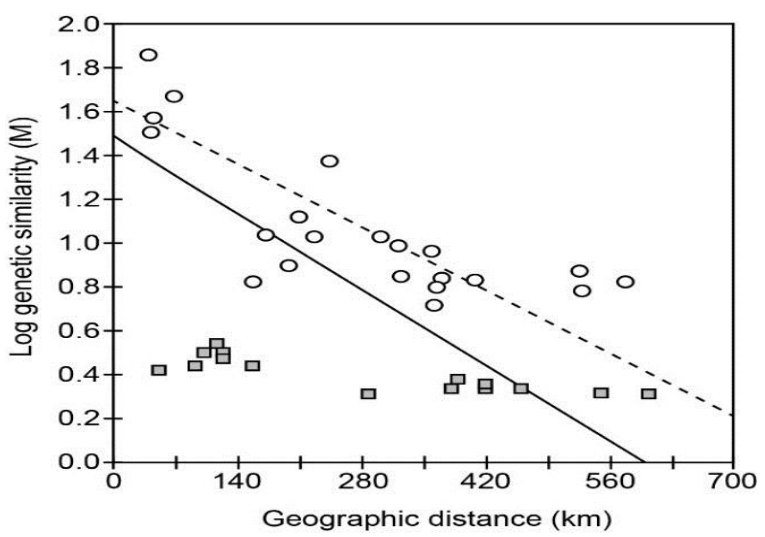

Figure 3. Analysis of isolation by distance (IBD) for microsatellite loci. Levels of log genetic similarity (M) are plotted against geographical distances $(\mathrm{km})$ for pairwise comparisons of all nine sampled locations (solid line; $r^{2}=$ $0.175, P=0.025)$ and all locations except Jackson and Gros Ventre (dotted line; $r^{2}=0.606, P=0.001$ ). Pairwise comparisons including Jackson and Gros Ventre are shown with a grey square. $P$-values represent significance of IBD using Mantel's test (10,000 permutations).

Table 3. Migration rates among greater sage-grouse populations using the program BAYESASS. Values shown are the means of the posterior distributions of $\mathrm{m}$, the migration rate into each population, and their respective $95 \%$ credible set in parentheses. Values along the diagonal (in bold) are the population of individuals derived from the source population each generation. Migration rates $\geq 0.100$ are underlined. Populations are based on results from STRUCTURE with Pinedale/Casper and Powder River/SE Montana (MT) identified as separate populations.

\begin{tabular}{|c|c|c|c|c|}
\hline Migration into: & $\begin{array}{l}\text { Migration from: } \\
\text { Jackson }\end{array}$ & Gros Ventre & Pindale/Casper & Powder R/SE MT \\
\hline Jackson & $\begin{array}{l}\mathbf{0 . 9 8 3} \\
(0.964-1.002)\end{array}$ & $\begin{array}{l}0.006 \\
(-0.006-0.018)\end{array}$ & $\begin{array}{l}0.006 \\
(-0.005-0.016)\end{array}$ & $\begin{array}{l}0.006 \\
(-0.005-0.016)\end{array}$ \\
\hline Gros Ventre & $\frac{0.100}{(0.002-0.198)}$ & $\begin{array}{l}\mathbf{0 . 8 6 5} \\
(0.763-0.966)\end{array}$ & $\begin{array}{l}0.018 \\
(-0.016-0.052)\end{array}$ & $\begin{array}{l}0.017 \\
(-0.015-0.049)\end{array}$ \\
\hline Pinedale/Casper & $\begin{array}{l}0.006 \\
(-0.004-0.015)\end{array}$ & $\begin{array}{l}0.011 \\
(-0.005-0.027)\end{array}$ & $\begin{array}{l}\mathbf{0 . 9 6 3} \\
(0.933-0.992)\end{array}$ & $\begin{array}{l}0.021 \\
(-0.004-0.046)\end{array}$ \\
\hline $\begin{array}{l}\text { Powder R/SE } \\
\text { MT }\end{array}$ & $\begin{array}{l}0.003 \\
(-0.003-0.008)\end{array}$ & $\begin{array}{l}0.003 \\
(-0.003-0.009)\end{array}$ & $\begin{array}{l}0.006 \\
(-0.003-0.016)\end{array}$ & $\begin{array}{l}\mathbf{0 . 9 8 8} \\
(0.976-1.000)\end{array}$ \\
\hline
\end{tabular}

Effective population size

Effective population sizes varied among sampled populations (Table 1). Jackson, Gros Ventre, 
and North Powder River populations had relatively small $\mathrm{Ne}$ (i.e. $<100$, upper $95 \% \mathrm{CI}<140$ individuals), while the remaining sampled populations were of large size with some exceeding the ability of the method to estimate Ne accurately and identified as infinity (Table 1; see Waples, 2006)

\section{$\uparrow \quad$ DISCUSSION}

Significant population genetic differentiation exists between Jackson and sampled sage-grouse populations in Wyoming and SE Montana, including those in close geographic proximity to Jackson (i.e., Pinedale and, to a lesser extent, Gros Ventre; Figure 2), while the remaining populations appear to show an overall IBD pattern of population structure similar to other studies investigating sage-grouse population connectivity using genetic methods (Oyler-McCance 2005; Bush et al. 2011; Figure 3). These results have important implications for the future management of sage-grouse in northwest Wyoming. The lack of genetic connectivity, coupled with small $N_{\mathrm{e}}$, and low genetic diversity, suggest that Jackson and Gros Ventre may require immediate attention to prevent local extinction; however, depending on the timing of isolation (pre- vs. post-European settlement), differing management strategies are required for securing a long-term viable population.

In 1948 and 1949, a total of 359 sage-grouse (269 adults and 90 juveniles) were transported into the Jackson Hole valley from Eden Valley, WY (Sweetwater County), ca. $35 \mathrm{~km}$ south of the south Pinedale sampling area (Patterson 1952). At the time, Patterson estimated a total population size of ca. 500 individuals based on total maximum lek counts.. Lek counts collected during the present study period were approximately half as compared to lek counts collected by Patterson (1952). Estimates from 1950 and 1951, derived from band sightings of relocated grouse, suggested that $9.5 \%$ and $11 \%$ of the strutting birds had been relocated to Jackson Hole, respectively (Patterson 1952). Patterson suggested that few adults established in relocated areas, whereas released juveniles regularly established in the second season following their relocation. No systematic surveys or estimates were produced to estimate the percentage of relocated females $(n=95)$ that bred. Our results suggest that either the relocated birds did not enter the effective breeding population or that the strength of genetic drift was sufficient to change the allele frequencies of the Jackson population relative to other populations within the past 60 years. Given the degree of genetic differentiation between Jackson and the surrounding regions, it is also possible that the Jackson population has developed morphological or behavioral differences that resulted in the relocated birds being precluded from breeding, as has happened with the divergence of plumage and vocalizations in Gunnison sage-grouse from greater sage-grouse (Young et al. 1994). More data are needed to elucidate any differences in appearance, sound, or strutting behavior between populations.

In other areas, relocation has been used as a management tool to help boost genetic diversity, such as for sage-grouse populations in Utah (Baxter et al. 2008, 2013) and California (Bell and George 2012; see also Reese and Connelly 1997) and other lek-breeding species such as greater prairie-chicken (Tympanuchus cupido pinnatus) in Illinois (Westemeier et al. 1998). However, despite a large number of sage-grouse being relocated into Jackson from a larger population sixty years ago, the contemporary Jackson population is isolated, suggesting that the population may require supplementation indefinitely for long-term management of this population if it remains of small size similar to its current population size. For species with similar life history requirements that are also in decline, such as the greater prairie-chicken, translocation of birds into small isolated populations have caused initial increases in genetic diversity and fitness (i.e., hatching successes; Bouzat et al. 2009); however, in order to produce a self-sustaining population, long term management goals require an increase in habitat connectivity, quantity, and quality (Bouzat et al. 2009). This is likely the case with small recently isolated sage-grouse populations as well.

To what degree recent changes in the landscape near Jackson and surrounding areas have influenced sage-grouse dispersal patterns in northwest Wyoming is not known, but human mediated reduction in connectivity to the large core population in Pinedale may have contributed to the isolation detected in the current study. There is evidence to suggest that other species' dispersal and migration patterns to and from Jackson Hole have been affected over a similar time period. For example, a large annual historic elk migration event once extended through Jackson to southwest Wyoming during the fall and winter, but became restricted north of Jackson by the end of the $19^{\text {th }}$ century to an area that is now designated as the National Elk Refuge largely due to an expanding human population and habitat alteration (Cromley 2000). Both Jackson and Gros Ventre sagegrouse populations are located approximately $130 \mathrm{~km}$ to the north of the most northern Pinedale population sampled in this study, which is less than half the distance between Pinedale and Casper populations (Figure 1). As geographical features such as mountains 
likely act as the primary dispersal barriers for Jackson sage-grouse, it is possible that migration routes to the south of the valley existed before European settlement but have now been altered by human activity. For example, the city of Jackson, increased land cultivation, and/or fossil fuel development south of Jackson (i.e. Pinedale Anticline Project in Sublette County) may have been sufficient to disrupt the already limited dispersal routes between Jackson and Pinedale. In the 1950's, approximately 9,425 ha of sagebrush habitat was available for sage-grouse in the southern portion of Jackson, roughly $19 \%$ less than pre-settlement estimates of 11,579 ha. Currently, only 6,674 ha of sagebrush habitat exists and supports a population of roughly half that in the 1950's (Bedrosian et al. 2010). While the habitat loss within Jackson may or may not contribute to the overall genetic isolation of the valley, reduction in habitat and/or altered connectivity with core populations may be an important factor in reducing population size and increased inbreeding.

Despite significant pairwise genetic differentiation between Jackson, Gros Ventre, and Pinedale (Figure 2), the genetic data also indicated that contemporary asymmetric gene flow exists between areas in northwest Wyoming with Gros Ventre possibly acting as a sink and Jackson and Pinedale as independent source populations with no gene flow occurring in opposite directions. Results from BAYESASS indicated a $\sim 10 \%$ immigration rate from Jackson into the Gros Ventre population with a lesser degree of genetic contribution derived from Pinedale ( 2\%; Table 3$)$. Other species such as pronghorn that also breed in Grand Teton National Park migrate south each year using the Gros Ventre River Drainage system as a corridor, thereby remaining connected to their wintering grounds in the Pinedale area (Sawyer et al. 2005). More work is needed to determine to what extent sage-grouse are currently using the Gros Ventre River Drainage for contemporary dispersal between areas and/or to determine factors that are limiting dispersal from Pinedale into Gros Ventre and Jackson using a similar route observed with pronghorn. These results do suggest that maintaining connectivity between the Gros Ventre and Jackson populations is supported and that the two areas should be managed as subpopulations (e.g., Waples and Gaggiotti 2006) with Gros Ventre dependent on dispersing individuals from Jackson.

However, it remains uncertain whether the Jackson and Gros Ventre populations were in fact connected to populations such as Pinedale for much longer periods of time prior to European settlement, similar to Gunnison sage-grouse (C. minimus; Young et al. 2000). For example, Jackson is surrounded by high elevation forest, including multiple mountain ranges (i.e. Teton, Wyoming, Wind River, Gros Ventre ranges, Figure 1) that most likely limit sage-grouse dispersal. If this is the case, then management should focus more on maintaining adequate habitat required by the population for long-term sustainability (e.g., Johnson et al. 2009) as opposed to introgression of genes that may result in outbreeding depression (Frankham et al. 2011). Although no formal investigation has been conducted to determine whether sage-grouse in northwest Wyoming differ from other greater sage-grouse based on morphology or behavior, the population's geographic location and early historic records (Schroeder et al. 2004; Figure 1) suggest that the population may have been isolated prior to European settlement.

Unique habitat differences (i.e., elevation, annual precipitation) do exist between Jackson/Gros Ventre and to the other areas sampled for this study. If sufficient time has passed following isolation, habitat differences may then cause differences to develop among sage-grouse populations resulting in reproductive isolation (i.e., ecological speciation; Schluter 2009; Nosil 2012). The genetic differentiation observed with STRUCTURE (Figure 2) and BAPS corresponds to the level I ecoregion delineation for the state of Wyoming (see Commission for Environmental Cooperation Working Group, 1997; Olson et al. 2001; Figure 1). If ecological differences are sufficient, local adaptation may further limit contemporary gene flow, eventually resulting in separate species, similar as happened with Gunnison sage-grouse (Young 2000) and red crossbill (Loxia curvirostra complex; Benkman 2003; Smith and Benkman 2007; Smith et al. 2012). Some evidence suggests that the sage-grouse in Jackson utilize different habitats than other sage-grouse populations (Chong et al. 2011), concurrent with the theory of local differences arising as a result of different ecological pressures. Given that the differences in ecoregions corresponded to genetic differentiation among the sage-grouse populations in this study, further investigation is warranted to determine the role of different habitat characteristics influencing gene flow across the entire distribution of greater sage-grouse and whether unique adaptations exist within the Jackson and Gros Ventre populations that may suggest that they are diverging by ecological speciation from other sage-grouse populations.

In addition to being small and geographically and genetically isolated, both Jackson and Gros Ventre sage-grouse populations also possess significantly reduced levels of neutral genetic diversity compared to 
the large core populations in Pinedale. Populations that are small and isolated are subject to exponential loss of genetic diversity over time through genetic drift at a rate that depends on their effective population size $\left(N_{e}\right.$; Frankham 1996; Frankham et al. 2009). Therefore, because Jackson and Gros Ventre sagegrouse populations possess small $N_{\mathrm{e}}$, they are expected to lose more genetic diversity compared to larger populations over the same time period. Reduction in genetic diversity in small, isolated populations has been shown to negatively influence individual and population fitness due to increased inbreeding (Keller 1998; Daniels 2000; Liberg 2005; Blomqvist et al. 2010; also see Keller and Waller 2002). Inbreeding has resulted in decreased immunocompetence, reproductive success, and survival among multiple bird species (Charpentier et al. 2008; Frankham et al. 2009; Blomqvist et al. 2010; Hammerly et al. 2013). Thus, inbreeding depression presents a potential risk for small, isolated populations with reduced genetic diversity, such as the Jackson and Gros Ventre sagegrouse populations observed in this study.

\section{$\uparrow \quad$ CONCLUSIONS}

Identifying isolated populations of greater sage-grouse is a conservation priority given the extent of recent land use changes throughout the species' distribution. It has been shown that maintaining isolated peripheral populations is important for protecting unique genetic variability, which should prove useful for long-term persistence of a species (Channell and Lomolino 2000; Nielsen et al. 2001; Willi et al. 2006; Peterman et al. 2013). Thus, identifying and managing isolated populations in order to prevent their extinction should contribute to the long-term survival of a species.

While the present study identified Jackson and Gros Ventre as isolated sage-grouse populations, it is not known if isolation was caused primarily by recent human mediated changes to the landscape or more historic processes. Further work is currently underway to determine whether recent anthropogenic activities contributed to their isolation. Regardless of recent or historic processes, however, management priority should focus on preventing further reduction in current population size in an effort to minimize the rate of genetic diversity loss.

\section{$\downarrow \quad$ ACKNOWLEDGEMENTS}

This study was made possible due to collaborations with multiple individuals and organizations. We thank Matt Holloran, Rusty Kaiser, Tom Maechtle, and Melissa Foster for providing samples. Sara Oyler-McCance (USGS) provided guidance on the choice of microsatellite loci. Funding was provided by Craighead Beringia South, Wyoming Game and Fish Department, Grand Teton National Park, the Jackson Hole Airport, UWNPS Research Station, Community Foundation of Jackson Hole, Bridger-Teton national Forest, Big Horn Environmental Consultants, and private foundations and individuals.

\section{$\downarrow$ Literature CITED}

Aldridge CL, Nielsen SE, Beyer HL, Boyce MC, Connelly JW, Knick ST. 2008. Range-wide patterns of greater sage-grouse persistence. Diversity and Distributions. 14:983-994.

Baillie JEM, Hilton-Taylor C, Stuart S, editors. 2004. IUCN red list of threatened species TM. A global species assessment. IUCN.

Baker MF, Eng RL, Gashwiler JS, Schroeder MH, Braun CE. 1976. Conservation committee report on effects of alteration of sagebrush communities on the associated avifauna. The Wilson Bulletin. 88:165-171.

Baxter RJ, Flinders JT, Mitchell DL. 2008. Survival, movements, and reproduction of translocated Greater Sage-Grouse in Strawberry Valley, Utah. The Journal of Wildlife Management. 72:179-186.

Baxter RJ, Larsen RT, Flinders JT. 2013. Survival of resident and translocated greater sage-grouse in Strawberry Valley, Utah: A 13-year study. The Journal of Wildlife Management. 77:802-811.

Bell CB, George TL . 2012. Survival of Translocated Greater Sage-Grouse Hens in Northeastern California, Western North American Naturalist. 3:369-376.

Bedrosian B, Crandall, R, Craighead D. 2010. Jackson Hole sage-grouse project completion report: 2007-2009. Unpublished Report. Craighead Beringia South. http://beringiasouth.org/Websites/beringiaso uth/images/Grouse Report Final.pdf.

Accessed 7.17.2013 
Benkman CW. 2003. Divergent selection causes the adaptive radiation of crossbills. Evolution. 57:1176-1181.

Blomqvist D, Pauliny A, Larsson M, Flodin LA. 2010. Trapped in the extinction vortex? Strong genetic effects in a declining vertebrate population. BMC Evolutionary Biology. 10:33.

Bouzat JL, Johnson JA, Toepfer JE, Simpson SA, Esker TL, Westemeier RL. 2009. Beyond the beneficial effects of translocations as an effective tool for the genetic restoration of isolated populations. Conservation Genetics. 10:191-201.

Bush K, Dyte C, Moynahan B, Aldridge C, Sauls H, Battazzo A, Walker B, Doherty K, Tack J, Carlson J, Eslinger D, Nicholson J, Boyce M, Naugle D, Paszkowski C, Coltman D .2011. Population structure and genetic diversity of Greater Sage-grouse (Centrocercus urophasianus) in fragmented landscapes at the northern edge of their range. Conservation Genetics.12:527-542.

Caizergues A, Rätti O, Helle P, Rotelli L, Ellison L, Rasplus JY. 2003. Population genetic structure of male black grouse (Tetrao tetrix L.) in fragmented vs. continuous landscapes. Molecular Ecology. 12:2297-2305.

Caizergues, A, Dubois S, Loiseau A, Mondor G, Rasplus JY. 2001. Isolation and characterization of microsatellite loci in black grouse (Tetrao tetrix). Molecular Ecology Notes. 1:36-38.

Channell, R, Lomolino, MV. 2000. Dynamic biogeography and conservation of endangered species. Nature. 403:84-86.

Charpentier MJ, Williams CV, Drea CM. 2008. Inbreeding depression in ring-tailed lemurs (Lemur catta): genetic diversity predicts parasitism, immunocompetence, and survivorship. Conservation Genetics. 9:1605-1615.

Chong G, Wetzel W, Holloran M. 2011. Greater sagegrouse of Grand Teton National Park: Where do they roam. Park Science. 27:36-43.
Commission for Environmental Cooperation Working Group. 1997. Ecological regions of North America - toward a common perspective: Montreal, Commission for Environmental Cooperation. $71 \mathrm{p}$.

Corander J, Marttinen P, Sirén J, Tang J. 2008a. Enhanced Bayesian modeling in BAPS software for learning genetic structures of populations. BMC Bioinformatics. 9:1-14.

Corander J, Marttinen P. 2006 Bayesian identification of admixture events using multi-locus molecular markers. Molecular Ecology. 15:2833-2843.

Corander J, Sirén J, Arjas E. 2008b. Bayesian Spatial Modeling of Genetic Population Structure. Computational Statistics. 23:111-129.

Cromley CM. 2000. Historical elk migrations around Jackson Hole, Wyoming. Yale School of Forestry and Environmental Studies Bulletin, 104:53-65.

Daniels SJ, Walters JR. 2000. Inbreeding depression and its effects on natal dispersal in redcockaded woodpeckers. The Condor. 102:482-491.

Delaney KS, Riley, Fisher RN. 2010. A Rapid, Strong, and Convergent Genetic Response to Urban Habitat Fragmentation in Four Divergent and Widespread Vertebrates. PloS One, 5:e12767.

Dixo M, Metzger JP, Morgante JS, Zamudio KR. 2009. Habitat fragmentation reduces genetic diversity and connectivity among toad populations in the Brazilian Atlantic Coastal Forest. Biological Conservation. 142:15601569.

Earl DA, vonHoldt BM. 2012. STRUCTURE HARVESTER: a website and program for visualizing STRUCTURE output and implementing the Evanno method. Conservation Genetics Resources. 4:359361.

Evanno G, Regnaut S, Goudet J. 2005. Detecting the number of clusters of individuals using the software STRUCTURE: a simulation study. Molecular Ecology. 14:2611-2620.

Excoffier L, Laval G, Schneider S. 2005. Arlequin (version 3.0): an integrated software package 
for population genetics data analysis. Evolutionary bioinformatics online, 1:47.

Ezard THG, Travis JMJ. 2006. The impact of habitat loss and fragmentation on genetic drift and fixation time. Oikos. 114:367-375.

Fahrig L. 2003. Effects of habitat fragmentation on biodiversity. Annual review of ecology, evolution, and systematics. 34:487-515.

Falush D, Stephens M, Pritchard JK. 2003. Inference of population structure using multilocus genotype data: linked loci and correlated allele frequencies. Genetics. 164:1567-1587.

Faubet P, Waples RS, Gaggiotti OE. 2007. Evaluating the performance of a multilocus Bayesian method for the estimation of migration rates. Molecular Ecology. 16:1149-1166.

Fei S, Cox J, Whittle A. 2011. A perfect storm may threaten Florida panther recovery. Frontiers in Ecology and the Environment. 9:317-318.

Frankham R. 1996. Relationship of genetic variation to population size in wildlife. Conservation Biology. 10:1500-1508.

Frankham R. 2005. Genetics and extinction. Biological Conservation. 126:131-140.

Frankham R. Balleu JD, Eldridge NDB, Lacy RC, Ralls K, Dudash MR, Femster CB. 2011. Predicting the probability of outbreeding depression. Conversation Biology 25: $465-$ 475.

Frankham R, Ballou J, Briscoe D. 2009. Introduction to Conservation Genetics. Cambridge University Press. New York, NY.

Garton EO, Connelley JW, Horne JS, Hagen CA, Moser A, Schroeder MA. 2011. Greater Sage-Grouse dynamics and probability of persistence. In: Knick ST, Connelly JW (editors). Greater Sage-Grouse: ecology and conservation of a landscape species and its habitats. Studies in Avian Biology (38). University of California Press, Berkeley, CA. p 293-381.

Goudet J. 1995. FSAT (version 1.2): a computer program to calculate $F$-statistics. Journal of Heredity. 86:485-486.
Hammerly SC, Morrow ME, Johnson JA. 2013. A comparison of pedigree- and DNA-based measures for identifying inbreeding depression in the critically endangered Attwater's Prairie-chicken. Molecular Ecology, in press.

Henle K, Lindenmayer DB, Margules CR, Saunders DA, Wissel C. 2004. Species survival in fragmented landscapes: where are we now? Biodiversity and Conservation. 13:1-8.

Holloran, MJ Anderson, SJ. 2004. Greater sage-grouse seasonal habitat selection and survival in Jackson Hole, Wyoming Research Completion Report. University of Wyoming Cooperative Fish and Wildlife Research Unit, Laramie

Jakobsson M, Rosenberg NA. 2007. CLUMPP: a cluster matching and permutation program for dealing with label switching and multimodality in analysis of population structure. Bioinformatics. 23:1801-1806.

Jensen JL, Bohonak AJ, Kelley ST. 2005. Isolation by distance, web service. BMC Genetics. 6:13. v.3.23 http://ibdws.sdsu.edu/

Johnson JA, Tingay RE, Culver M, Hailer F, Clarke M, Mindell D. 2009. Long-term survival despite low genetic diversity in the critically endangered Madagascar fish-eagle. Molecular Ecology. 18:54-63.

Johnson, JA, Bellinger, MR, Toepfer, JE, Dunn, P 2004. Temporal changes in allele frequencies and low effective population size in greater prairie-chickens. Molecular Ecology. 13:2617-2630.

Johnson, JA, Toepfer, JE, Dunn, PO. 2003. Contrasting patterns of mitochondrial and microsatellite population structure in fragmented populations of greater prairiechickens. Molecular Ecology. 12:3335-3347.

Keller LF. 1998. Inbreeding and its fitness effects in an insular population of song sparrows (Melospiza melodia). Evolution. 52:240-250.

Keller LF, Waller DM. 2002 Inbreeding effects in wild populations. Trends in Ecology and Evolution. 17:230-241. 
Knick ST, Connelly W. 2011. Greater Sage-Grouse and sagebrush: an introduction to the landscape. Im: Knick ST, Connelly JW (editors). Greater Sage-Grouse: ecology and conservation of a landscape species and its habitats. Studies in Avian Biology (vol. 38). University of California Press, Berkeley, CA. p 1-9.

Knick ST, Dobkin, DS, Rotenberry JT, Schroeder MA, Vander Haegen WM, van Riper III C (2003) Teetering on the edge or too late? Conservation and research issues for avifauna of sagebrush habitats. The Condor. 105.611-634.

Knick ST, Rotenberry JT. 2002. Effects of habitat fragmentation on passerine birds breeding in intermountain shrubsteppe. Studies in Avian Biology. 25:130-140.

Kyle CJ, Strobeck C. 2002. Connectivity of peripheral and core populations of North American wolverines. Journal of Mammalogy, 83:1141-1150.

Leberg PL. 2002. Estimating allelic richness: effects of sample size and bottlenecks. Molecular Ecology, 11:2445-2449.

Lewis PO, Zaykin D. 2001. Genetic Data Analysis: Computer Program for the Analysis of Allelic Data, Version 1.0 (d16c). University of Connecticut, Storrs, Connecticut.

Liberg O, Andrén H, Pedersen HC, Sand H, Sejberg D, Wabakken P, Åkesson $\mathrm{M}$, Bensch S. 2005. Severe inbreeding depression in a wild wolf Canis lupus population. Biology Letters. 1:17-20.

Madsen T, Shine R, Olsson M, Wittzell H. 1999. Restoration of an inbred adder population. Nature. 402:34-35.

Nielsen JL, Scott JM, Aycrigg JL. 2001. Endangered species and peripheral populations: cause for conservation. (Letter to the Editor). The Free Library: Endangered Species Update. 18:194-197.

Nosil P. 2012. Ecological Speciation. Oxford University Press. New York, NY.

Olson DM, Dinerstein E, Wikramanayake ED, Burgess ND, Powell GVN, Underwood FC,
D'amico JA, Itoua I, Strand HE, Morrison JC, Loucks CJ, Allnutt TF, Ricketts T, Kura Y, Lamoreux JF, Wettengel WW, Hedao P, Kassem KR. 2001. Terrestrial Ecoregions of the World: A New Map of Life on Earth. BioScience. 51:933-938.

Oyler-McCance S, Taylor S, Quinn T. 2005. A multilocus population genetic survey of the Greater Sage-grouse across their range. Molecular Ecology. 14:1293-1310.

Oyler-McCance SJ, St John J. 2010. Characterization of small microsatellite loci for use in non invasive sampling studies of Gunnison Sagegrouse (Centrocercus minimus). Conservation Genetics Resources. 2:17-20.

Oyler-McCance SJ, Stricker CA, St. John J, Braun CE, Wann GT, O'Donnell MS, Aldridge CL. 2011. Effects of climate change on nutrition and genetics of White-tailed Ptarmigan. In: Sandercock BK, Martin K, Segelbacher G (editors). Ecology, conservation, and management of grouse. Studies in Avian Biology (no. 39). University of California Press, Berkeley, CA. p 283-294.

Patterson RL. 1952. The sage grouse in Wyoming. Sage Books, Inc. Denver.

Peakall R, Smouse PE. 2006. GenAlEx 6: genetic analysis in Excel. Population genetic software for teaching and research. Molecular Ecology Notes. 6:288-295.

Peterman WE, Feist SM, Semlitsch RD, Eggert LS. 2013. Conservation and management of peripheral populations: Spatial and temporal influences on the genetic structure of wood frog (Rana sylvatica) populations. Biological Conservation. 158:351-358.

Piertney SB, Höglund J. 2005. Polymorphic microsatellite DNA markers in black grouse (Tetrao tetrix). Molecular Ecology Notes. 1:303-304.

Prevedello JA, Vieira MV. 2010. Does the type of matrix matter? A quantitative review of the evidence. Biodiversity and Conservation, 19:1205-1223.

Pritchard JK, Stephens M, Donnelly P. 2000. Inference of population structure using multilocus genotype data. Genetics 155: 945-959. 
Ratkiewicz M, Matosiuk M, Kowalczyk R, Konopiński MK, Okarma H, Ozolins J, Männil P, Ornicans A, Schmidt K. 2012. High levels of population differentiation in Eurasian lynx at the edge of the species' western range in Europe revealed by mitochondrial DNA analyses. Animal Conservation. 15:603-612.

Reed DH. 2004. Extinction risk in fragmented habitats. Animal Conservation. 7:181-191.

Reese KP, Connelly JW. 1997. Translocations of Sage Grouse Centrocercus urophasianus in North America. Wildlife Biology. 3:235-241.

Rice WR. 1989. Analyzing tables of statistical tests. Evolution. 43:223-225.

Rosenburg NA. Distruct: a program for the graphical display of population structure available at: http://www,stanford.edu/group/rosenberglab /software/distruct.html.

Rowland MM, Suring LH, Leu M, Knick ST, Wisdom MJ. 2011. Sagebrush-associated species of conservation concern. In: Sagebrush Ecosystem Conservation and Management: Sagebrush Ecosystem Conservation and Management. 46-68.

Rowland MM, Wisdom MJ, Suring LH, Meinke CW. 2006. Greater Sage-grouse as an umbrella species for sagebrush-associated vertebrates. Biological Conservation. 129:323-335.

Sala OE, Chapin III FS, Armesto JJ, Berlow E, Bloomfield J, Dirzo R, Huber-Sanwald E, Huenneke LF, Jackson RB, Kinzig A, Leemans R, Lodge DM, Mooney HA, Oesterheld M, LeRoyPoff N, Sykes MT, Walker BH, Walker M, Wall DH. 2000. Global biodiversity scenarios for the year 2100. Science. 287:1770-1774.

Sawyer H, Lindzey F, McWhirter D. 2005. Mule deer and pronghorn migration in western Wyoming. Wildlife Society Bulletin. 33:1266-1273.

Sawyer H, Nielson RM, Lindzey F, McDonald LL. 2006. Winter habitat selection of mule deer before and during development of a natural gas field. The Journal of Wildlife Management. 70:396-403.
Schroeder MA, Aldridge CL, Apa AD, Bohne C, Bunnell SD. 2004. Distribution of SageGrouse in North America. Condor. 106:363376.

Schluter D. 2009. Evidence for ecological speciation and its alternative. Science, 323:737-741.

Segelbacher G, Höglund J, Storch I. 2003. From connectivity to isolation: genetic consequences of population fragmentation in capercaillie across Europe. Molecular Ecology. 12:1773-1780.

Segelbacher G, Paxton RJ, Steinbrück G, Trontelj P, Storch I. 2000 Characterization of microsatellites in capercaillie Tetrao urogallus (AVES). Molecular Ecology. 9:1919-1952.

Slatkin M. 1993. Isolation by distance in equilibrium and non-equilibrium populations. Evolution. 264-279.

Smith JW, Benkman CW. 2007. A coevolutionary arms race causes ecological speciation in crossbills. The American Naturalist. 169:455-465.

Smith JW, Sjoberg SM, Mueller MC, Benkman CW. 2012. Assortative flocking in crossbills and implications for ecological speciation. Proceedings of the Royal Society B. 279:4223-4229.

Soule ME, Mills LS. 1998. No need to isolate genetics. Science 282: 1658-1659.

U.S. Fish and Wildlife Service. 2003. Endangered and threatened wildlife and plants; final rule to list the Columbia Basin distinct population segment of the pygmy rabbit (Brachylagus idahoensis) as endangered. Federal Register 68:10388-10409.

Walker BL, Naugle DE, Doherty KE. 2007. Greater Sage-Grouse population response to energy development and habitat loss. Journal of Wildlife Management. 71:2644-2654.

Waples RS. 2006. A bias correction for estimates of effective population size based on linkage disequilibrium at unlinked gene loci. Conservation Genetics, 7:167-184.

Waples RS, Do C. 2008 LDNE: a program for estimating effective population size from 
133

data on linkage disequilibrium. Molecular Ecology Resource., 8:753-756.

Waples RS, Gaggiotti O. 2006 What is a population? An empirical evaluation of some genetic methods for identifying the number of gene pools and their degree of connectivity. Molecular Ecology, 15:1419-1439.

Weir BS, Cockerham CC. 1984. Estimating FStatistics for the analysis of population structure. Evolution. 38:1358-1370.
Westemeier RL, Brawn JD, Simpson SA, Esker TL, Jansen RW, Walk JW, Kershner EL, Bouzat JL, Paige KN. 1998. Tracking the Long-Term Decline and Recovery of an Isolated Population. Science. 282:1695-1698.

Willi Y, Van Buskirk J, Hoffmann AA. 2006. Limits to the adaptive potential of small populations. Annual Review of Ecology, Evolution, and Systematics. 433-458.

Wilson GA, Rannala B. 2003. Bayesian inference of recent migration rates using multilocus genotypes. Genetics. 163:1177-1191.

Young JR, Hupp JW, Bradbury JW, Braun CE. 1994. Phenotypic divergence of secondary sexual traits among sage grouse, Centrocercus urophasianus, populations. Animal Behavior. 47:1353-1362.

Young JR, Braun CE, Oyler-McCance SJ, Hupp JW, Quinn TW. 2000. A new species of sagegrouse (Phasianidae: Centrocercus) from southwestern Colorado. Wilson Bulletin. 112:445-453. 